\title{
Making economics more relevant: an interview with Geoffrey Hodgson
}

GEOFFREY M. HODGSON (Watford, England, 1946) is research professor at the University of Hertfordshire Business School, UK. He is editor-inchief of the Journal of Institutional Economics and a member of the Academy of Social Sciences in the UK. He has published over 120 articles in academic journals and his books include Economics and institutions (1988), Economics and evolution (1993), Economics and utopia (1999), How economics forgot history (2001), The evolution of institutional economics (2004), and (with Thorbjørn Knudsen) Darwin's conjecture: the search for general principles of social and economic evolution (2010).

Professor Hodgson is widely known for his extensive work on institutional economics, and his numerous contributions to a broad variety of topics in heterodox economics and social theory. His current research focuses on the theoretical and methodological foundations of institutional and evolutionary economics. In particular he is interested in the application of Darwinian principles to socio-economic evolution, the conditions underlying increasing socio-economic complexity, and the impact of increasing complexity in capitalist development.

During a visit to Erasmus University Rotterdam in November 2009 Professor Hodgson granted EJPE the opportunity to discuss many of these issues extensively. The interview ranged widely over such topics as the relationship between institutional and neoclassical economics; the methodological challenges in institutional economics; the potential role of biological and evolutionary ideas in the social sciences; and the role of economics and economists in the recent economic crisis and how the profession should change.

EJPE'S NoTE: This interview was conducted by Clemens Hirsch, PhD candidate at the Erasmus Institute for Philosophy and Economics (EIPE), Erasmus University Rotterdam, and currently visiting researcher at the Department of Social and Moral Philosophy at the University of Helsinki. 
EJPE: Professor Hodgson, you are one of the most well known contributors to contemporary institutional economics. However, your earlier career was quite different. Can you tell us how did you arrive at economics in general and how did you get interested in institutional economics in particular?

GEOFFREY HODGSON: My first degree was in mathematics and philosophy at the University of Manchester. As an undergraduate in the 1960s, I became interested in left-wing ideas-like many others at that time. I got interested in Marxism in general and in Marxist economics in particular. Eventually, I found myself publishing a few articles in that area but they were actually critical of the technical aspects of Marxist economics. That was unusual: I was sympathetic to Marxism, but I was also a critic. My criticisms were based on the then popular framework of Piero Sraffa (1960) and I did some post-graduate work in that area.

A double shift occurred in my thinking in the late 1970s and early 1980s. I became politically disenchanted with Marxism, particularly because of the way that Marxists responded to the free-market arguments of Friedrich Hayek and others. In the Thatcher era their response was very weak, but just as importantly, I thought that the foundational principles of Marxist theory were at fault. I still think there is a lot of validity in Marxism, but I was searching for an alternative perspective. One problem that particularly alerted me was the lack of any developed theory of the human agent in Marxism. Instead, all the explanatory work is done by the social structure: Marxists examine the social structure and then place agents in their positions in that structure. At least in classical versions of Marxism, that is deemed sufficient to explain agent behaviour. I thought that was a major shortfall.

But my dissent was not simply with Marxism. It was also with other versions of heterodox economics at the time. In the 1960s and 1970s at Cambridge, and some other places in the UK and USA, the dominant heterodoxies were either Marxist economics or post-Keynesian economics. Institutionalism was less influential, and was then completely absent in the UK. I turned to the old institutionalism of Veblen in the early 1980s because it had more persuasive psychological underpinnings. I became interested in psychology and critiques of the standard rationality assumptions in economics. I was also influenced by Herbert Simon and by a number of other people, including Hayek and 
G. L. S. Shackle. I started a long march that took me away from Marxism and - through Veblen - got me interested in evolutionary theory as well.

For my work on Marxist theory in the 1970s I had a brief international fame. But I walked away from that way of approaching economic analysis. For about ten years I was not invited anywhere. Things began to change after I published my book Economics and institutions in 1988.

So you were already interested in institutionalist issues before new institutionalism began to emerge in the mid 1970s?

Part of my critique of Marxism was also that it failed to take institutions sufficiently into account. In 1977 I published a book called Socialism and parliamentary democracy, which critiqued Marxism for failing to take the institutional importance of parliamentary democracy into account. Parliamentary democracy is normatively important. But in practical terms it is also an institution with which people have to engage in one way or another. And it is a source of political legitimacy. At the time many Marxists had a crude insurrectionary perspective, where every such institution had to be overturned. I argued against that. So I think there is an institutionalist thread going right back to my Marxist period.

You mentioned that institutions had been ignored-or not properly taken into account-in economics for a long period of time. Why do institutions matter in economics?

Institutions matter because there is no society or economy without institutions. If you define institutions-as many people do-as systems of rules for guiding human conduct, then everything we do is bounded by institutions. We are conversing in a language that has rules. If we do not follow those rules we reduce the probability of being understood. We have just been for lunch, there we follow rules: about appointments; about paying; about table manners. Often we do not think about it, we just follow the rules all the time. So, any social activity is permeated with rules and thus rule systems-institutions-are unavoidable.

New institutional economics today is a flourishing but also quite heterogeneous field of research. How would you draw the current boundaries of the field and how would you position your own work within those boundaries? 
When the new institutional economics emerged in the current era with the publication of Oliver Williamson's 1975 book Markets and hierarchies, and several others around that time, it adopted quite a narrow project. This was to take individuals as given and then to try explain how institutions emerge. This struck me immediately as an incomplete story because, again, you have the problem of explaining individual preferences and dispositions. A shortcut is made in the familiar way, as in much of mainstream economics, to simply assume a preference function and not to explain where it comes from. That had already been my concern about other systems of thought, including Marxism. There was no explanation of individual psychology, individual agency, and so on. I reacted against the new institutionalists for that reason, although I was very sympathetic to their concern with real institutions. That was a big change in economics, because previously institutions had often been ignored. The concern with institutions, like the firm and the state, was an extremely important move. I also think that core concepts like transaction costs are important and real, and the logic of transaction cost arguments is powerful. I do not think it is the whole story, but I think it is an important part of the story about why firms exist.

It further became clear, particularly by the 1990s, that there were developments within the new institutionalism that offered a broadening agenda. New institutionalists such as Douglass North (1990; 1994) and Masahito Aoki $(1990 ; 2001)$ were saying things that were much more consistent with my position. They talked of the need for explanations of institutional evolution and of individual preferences. North developed a theme, which is now very prominent in his work, about ideology and the role of ideas. He writes of the need to learn from cognitive science and psychology. That was exactly my agenda. So I perceived a convergence with North and this wing of the new institutionalism.

Today I would sum up the new institutionalism as very heterogeneous. I find myself comfortable with many aspects of it and I am very critical of other aspects, but I am happy to swim in that pond. The old institutionalism is also very heterogeneous. A project I started in the 1990s and finished a few years ago was my two-volume history of the old institutionalism: How economics forgot history (2001), and The evolution of institutional economics (2004). My research for these books, which took many years, reinforced my view that the old institutionalism was actually very heterogeneous. 
Today I think there is enormous opportunity for the interchange of ideas and conversation between different currents. I describe my own position as an eclectic with a strong Veblenian preference, because I think Veblen had a theoretical system that-although underdevelopedin many ways remains powerful today.

Do you think there are promising elements in old institutional economics, which have not been taken up by new institutional economics and should be given more attention?

Yes, several things. Psychology is already having an impact in the new institutionalism. But I would like to see that go much further, particularly with respect to theories of the firm and how organizations work more generally. That agenda is an exciting one and if it is pursued, it will give new insights. There is already some movement in that direction.

My research agenda after writing the two books just mentioned was to take up early work on evolution and show how evolutionary principles can and have to be brought in. Perhaps surprisingly for a social scientist, my argument is that the Darwinian core principles-of variation, selection, and retention-offer a general framework that helps us understand all complex evolving systems. This applies to social systems as well. It does not give us all the answers but it is a way of organizing our inquiry in those areas. Old and new institutionalists alike are concerned to explain change, and sometimes radical structural change, in systems. Darwinism offers a framework for further theoretical development in this area.

What about the relationship between new institutional economics and the neoclassical mainstream? It seems that new institutionalists vary in their assessment of the mainstream. Some are very critical about it whereas others essentially side with Oliver Williamson in seeing the new institutionalism as a strand of research compatible with, and largely complementary to, the mainstream. Your own work often is very critical of neoclassical economics. What is your motivation behind this assessment?

I define neoclassical economics in terms of the assumption of rational utility-maximizing agents with relatively well-defined choice sets. A principal aim is to try to explain how particular equilibria are formed through agents making choices and interacting with others in particular 
settings. The limitations of neoclassical economics have partly to do with its psychological assumptions and the thinness of the rationality assumption. When expressed in a broad and inclusive manner, the rationality assumption is not so much wrong as rather empty and really not that useful. Gary Becker, for instance, always has to bring in auxiliary assumptions to get anything out of it. Mark Blaug and others have made similar critical points concerning rationality.

One of my criticisms of Williamson is that he does not take context sufficiently into account. When people operate within institutional settings they take into consideration the norms and rules that prevail. We are social animals. We are strongly attuned to verbal and non-verbal signals, including body language and expressions of sympathy or anger. Such signals and emotions are all around us in all kinds of institutional and organizational settings. Hence when people go to work in the morning at nine o'clock and go into the firm they become moulded by those institutional and cultural settings. This 'downward causation', from institutions to individuals, is lacking in Williamson's story. He just adopts a comparative statics argument, like Coase did in 1937: Coase considers the relative transaction costs of two governance modes, the market versus the firm. But there is no discussion of how individuals are changed. The same individuals are maximizing the same preference function in both contexts. Williamson also adds an unnecessary but symptomatic twist concerning opportunism. Although some people are opportunistic it is not the main reason for the existence of the firm. Williamson's stress on opportunism also goes against the minority of mainstream economists who assume rationality but stress the possibility of altruism.

Last year Oliver Williamson and Elinor Ostrom received the Nobel Prize in Economics for their work on institutions. That adds to the two previous institutional economists, Ronald Coase (1991) and Douglass North (1993), who have been awarded Nobel Prizes as well. What are your thoughts on this choice and to what extent do you expect these prizes to raise the standing of new institutional economics within the economics profession?

Let me just make a quick amendment. There were two earlier institutional economists who got the Nobel Prize: Simon Kuznets in 1971, and Gunnar Myrdal in 1974. They were old institutionalists. At that time, before the full triumph of neoclassical formalism throughout 
the discipline, old institutionalists retained some mainstream respect and influence. That being said, I want to stress that despite my disagreements with Williamson's work, I am delighted that he and Elinor Ostrom got the Nobel Prize for their very important work on institutions and governance systems. It certainly puts institutional economics further up the agenda. The Nobel awards to Coase, North, and now to Williamson and Ostrom, have helped enormously to raise the prestige and profile of institutional inquiry. To get the Nobel Prize for work that is rigorous without necessarily being expressed in mathematical language provides a lesson for us all concerning the possibilities for making advances in economics that are not confined to mathematics. Williamson and Ostrom are not well-known for their mathematics. They are better known for their deep insights into the nature of institutions. Mathematics is an important tool; but without a rigorous conceptual framework and significant empirical inquiry it is of limited use.

There seems to be an important shared theme in your work and the work of Elinor Ostrom. Like Ostrom, you often emphasize the importance of informal institutions in explaining economic behaviour, and that what is really shaping human behaviour are the habits, norms, and routines that people have. How, then, do you see the explanatory role of both formal and informal institutions in economics? I have the impression that not very much work has been done yet to integrate both of these aspects in a systematic manner.

This is a very important and interesting question. A barrier to progress in this area is that the terms 'formal' and 'informal' institutions are used in different ways. Coming from a philosophical background like you, I am concerned to be precise about meanings. I have noticed at least three prominent definitions and formulations of the dichotomy between the formal and the informal (Hodgson 2006). For many, formal means legal institutions, and informal means rules that are not codified in law. But that is not the only usage of these terms and it is always important to be clear.

In my work, I emphasize the concept of 'habit'. Habits drive individual agents. Cognitive or behavioural dispositions-ways of thinking; ways of doing; ways of interpreting-are all expressions of habit. The habit concept gives you not only a means of understanding individual preferences or dispositions, but also a means of understanding how institutional settings and constraints can affect or 
change individuals. In a 2004 paper in the Journal of Economic Behavior and Organization, Thorbjørn Knudsen and I have done some agentbased modelling on this, where agents change their preferences or habits as a result of interacting with others and establishing particular kinds of behaviour. There is both upward and downward causation in the model, which provides a rigorous means to consider causal mechanisms operating in different directions.

In a lot of my writing up to last year, I emphasized that habits underpin institutions. That is a very Veblenian view. I think that is still true, but it misses an important part of the story concerning how laws and organizations work. Arguably, unless laws are rooted in habits, they are unenforceable. But the problem with that argument is that law is so vast and complex that no single person can embody all the habits corresponding to the legal system of The Netherlands, or Britain, or anywhere else. So how does it operate? Law involves an authority mechanism. The special habit in this case involves recognition of authority. Here I cite the Milgram experiments on authority. I reread Stanley Milgram's book Obedience to authority (1974) recently. He actually sets up an evolutionary argument for a disposition to recognize authority: it is an evolved mechanism that helps cohesion in groups. We recognize the legitimate authority of the legal system, the police's authority, and so on, and in many cases that is sufficient to get us to conform to laws.

As I explain in a 2009 paper in the Journal of Economic Issues (Hodgson 2009a), the relationship between habits and institutions is more complicated. The authority mechanism is a neglected key element in this story that helps us understand how certain types of formal institutions operate.

In much of my research I have focused on the firm as an institution. More recently I have turned to law as another institution. The way they operate is similar in some ways, but quite different in others. Legal authority has to do with the role of the state and the recognition by citizens of its legitimate authority. The legitimating mechanisms involve democracy and consent, at least in many modern societies. Within the firm it is a slightly different story. There are hierarchies within firms and authority rests on a different kind of legitimacy. Authority claims there are established through contract. We need to do much more research on the ways in which social structures and social positions have effects on individual acquiescence or rebellion. 
In your more recent writing one concept figures very prominently: 'generalized Darwinism'. Could you briefly explain the concept and its main benefits for theorizing about institutions, and more generally in the social sciences?

By generalized Darwinism I mean the abstraction and generalization of core Darwinian principles to other evolving complex systems. I learnt from my philosophy training and start with the ontology. I specify the phenomena that we are considering in this context as 'complex population systems'. These involve populations of entities which are heterogeneous to some degree and interact with each other, giving rise to complex patterns and outcomes. These entities need resources to survive and such resources are in some sense immediately scarce. To use Darwin's phrase: they face a 'struggle for existence'. Individual entities furthermore have the capacity to acquire solutions to certain problems concerning their survival and pass those solutions on to others. So there is a notion of information retention and replication. Note here that I am defining information in a very broad (ShannonWeaver) sense, involving an input signal and a reaction (see Shannon and Weaver 1949). Information in a narrowly defined human or interpretative sense is taken into account at a later and less general stage of the argument.

After specifying that ontology, I argue that an explanation of the evolution of the social system must involve the Darwinian principles of variation, selection, and replication or inheritance. Why? Because we have to explain that variation exists and how it persists in the system. Entities are degradable and can expire and we have to explain why some survive and others do not. And we have to explain how information solutions are stored and replicated or passed on from entity to entity. Without such explanations we have an incomplete story. Any complete scientific analysis of such a system must involve those elements.

Having specified the ontology, the case for generalized Darwinism becomes quite straightforward. Other evolutionary economists, such as John Foster (2005) and Ulrich Witt (1997), emphasize self-organization. That may be very important, but it does not give you a complete explanation. You still require the Darwinian principles. Self-organization can and does occur in both human society and in nature, but it is not the complete explanation, because it cannot explain why one selforganizing system survives rather than another. 
However, generalized Darwinism is not biological reductionism. It is not saying we have to explain social phenomena in biological or genetic terms. Whether you can or you cannot is partly an empirical issue. It is not something which is assumed at the outset by generalized Darwinism. Neither is it assumed that every outcome is efficient or that evolution is an optimizing process. In biological evolution the outcomes are not necessarily optimal-so too in social evolution. Survival does not always involve the fittest. Neither does this argument necessarily justify free market economics. It depends on the particular context and mechanisms involved.

Having established the agenda, the next step is to express the core concepts in a generalizable form. But one has to be careful not to bring in any unnecessary biological baggage with those generalized terms. That is particularly important with concepts like selection and replication. Fortunately, in both those areas a great deal of important work has been done, particularly by philosophers of biology since David Hull's important 1988 book Science as a process. This work helps us to move forward to specify these concepts in a manner that can apply to all complex population systems. They address the commonalities rather than the specifics.

In my work with Thorbjørn Knudsen (Hodgson and Knudsen 2010) we refine those concepts. We try to build on the work of others to improve their formulations. We also argue that the general replicatorinteractor distinction-which in biology is the genotype-phenotype distinction-is also vital to understand the process. There has been some questioning of the relevance of the replicator-interactor distinction, by both biologists and economists such as Richard Nelson. In response we defend the distinction and refine previous definitions of the replicator and interactor concepts.

What is the use of all this? First of all, I would defend the role of free inquiry in the academy, even in the absence of any known payoff. Today grant-awarding authorities and governments are too keen to insist that research must immediately show a business or other payoff. While I strongly believe we have a responsibility to society, demonstrating immediate payoffs is not the way that research works. Generalizing Darwinism is long-term research, concerning conceptual underpinnings. By its nature, we cannot predict how fruitful it will be. It is much based on scientific hunches. We simply have to pursue it, refine it, and see how far it goes. 
But we already have a glimpse of some payoff value. One thing that comes out of our abstract conceptual work is the importance of information and its replication. This might open some doors for understanding how human society and business institutions evolve. We also examine the conditions under which information-retention and replication create possibilities for future complexity, involving greater variation and more complex interactions. So I think we are in sight of middle-ranging theorizing-after Robert Merton's term for theory that is less abstract, but more than inductive empirical work-although we are not quite there yet.

There is one thing about evolutionary frameworks that I find somewhat puzzling. Isn't it always possible to come up with an evolutionary story ex post? So the framework is likely to be consistent with a broad range of social phenomena, but in order to give it explanatory bite isn't it necessary to be much more specific and explicit about how to falsify or verify evolutionary conjectures?

Again a good question. Several decades ago there was a debate involving Popper and others, concerning whether Darwinism is falsifiable. If Darwinism means the survival of the fittest and fitness is the capacity to survive, then you have a circular argument. It is a tautological formulation with no predictive value. Survivors survive because they are fit, and they are fit since they survive.

But this claim involves a misunderstanding of Darwinism. First, 'survival of the fittest' is an inexact formulation of Darwinism. Although Darwin adopted the term, it came originally from Herbert Spencer and Darwin had misgivings about it. Second, fitness itself is a problematic concept (Knudsen and I address that in our writing too). Philosophers of biology - and even biologists themselves-do not define fitness simply in terms of survival. They use proxies such as the propensity to produce offspring. In such cases the formulation ceases to be a tautology-it is potentially false. So the tautological point can be circumvented once one is careful about the concepts.

Your ex post argument is slightly different. It is partly true that evolutionary explanations are often backward-looking: they explain things that have already happened and are quite weak in predicting. And your argument would apply to biology as much as it would apply to any evolutionary process in the social domain. Yet, evolutionary biology is extraordinary powerful and successful as a science. Why so? The answer 
involves a combination of general frameworks and particular heuristics. Within the overarching Darwinian framework scientists bring in auxiliary hypotheses which have contingent value depending on the circumstances.

Similar arguments apply when we move to social evolution. The overarching framework is just that: it does not provide the detailed answers. You get explanatory value out of it by adding particularitiesparticular mechanisms, particular contexts, particular processes-within that framework. The important thing is that the framework helps us to understand key processes in a very complex situation. With varied interacting agents we can see though the tangled mess and identify some key processes at work. Among other things, we need to understand how business firms evolve and how human institutions interact with the natural environment. The agenda is potentially huge.

In which sense is your recent work on generalized Darwinism an elaboration or a generalization of your earlier writings on evolution? That is, the move from evolution to generalized Darwinism, is it just a terminological modification or does it imply major conceptual differences as well?

As early as the 1980s, Veblen influenced me greatly in terms of incorporating Darwinian and evolutionary ideas. I was surprised to discover that evolutionary economics had a different conception of what evolution meant and the Darwinism issue was mostly on the fringes. For example, in their 1982 book An evolutionary theory of economic change, Richard Nelson and Sidney Winter mention Darwin once in passing, and not for any analytical insight. They list a whole series of intellectual mentors but Darwin is not one of them. As another example, take the USA-based Association for Evolutionary Economics. I learned that the 'evolution' in their title does not mean Darwinism, despite their declared Veblenian origins and affinities. It simply means development. And when the International Schumpeter Association was formed in 1988, and announced the Journal of Evolutionary Economics, 'evolution' meant Schumpeter more than Darwin. Schumpeter himself however makes little reference to, or use of, Darwin.

It was rather strange that evolution suddenly reappeared in the social sciences, and in economics in particular, and yet it was unclear what it meant and the prominent Darwinian meaning was sidelined. My 1993 book Economics and evolution asked: What does this term mean 
and on what grounds might it be adopted in social science? As case studies in that book I look at Schumpeter, Veblen, Hayek, and others. I did not argue there for a generalized Darwinism framework-I became persuaded by that shortly afterwards. Various people, including Daniel Dennett (1995), triggered my fascination with that line of inquiry.

I have been interested in evolutionary ideas for a long time, but I always wanted to know what this term meant. I find that Darwinism provides us with the only satisfactory general framework for understanding the kind of processes we are looking at in human society over the long term.

There seems to be a current trend in social science of borrowing ideas and concepts from biology, such as Darwinism. Do you think that biology can be a fruitful source of ideas for the social sciences, and are there further biological ideas and concepts that you find particularly interesting?

I am with Alfred Marshall here. He saw biology as the Mecca of the economist. Biology is important for the social sciences because in both cases we have highly complex, variegated, interacting systems. The success of scientific explanation in biology, in its highly complex domain, is a lesson for economists.

But that does not mean that we should slavishly imitate everything we find out in biology. There are lots of analogies that do not work. There is nothing in society like the gene: the way replicators work in the social domain is very different from genes and other biological replicators. They both pass on information from entity to entity, but the mechanisms and the nature of that information are very different. We should not collapse economics into biology either by slavish imitation or by believing that biology offers the key to understanding everything social. Far from it. We have a lot of interesting work to do concerning biological influences on human behaviour but we still have to explain things partially in terms of culture and institutions.

So there are limits to biology as well. Another limit, which people often mistakenly raise as an objection, is that humans have important capacities which are absent in other species: deliberation, conscious prefiguration, intersubjective understanding, conjecturing what others think and intend, and trying to anticipate their behaviour through such conjectures. All this means that humans are special and the abstract apparatus of generalized Darwinism is inadequate. We have to build into 
that framework additional assumptions that are specific to human society. Here we learn much more from social theory, philosophy, psychology, and anthropology. Those answers become vitally important. So the extremely important observation that humans are different in terms of their mental capacities has to be taken into account in the evolutionary analysis. But this does not mean that you throw Darwinism out of the window. It means that you have to incorporate additional, more specific theories into its framework.

Could there be other inspirations from biology that are not yet exploited? Surely yes! One of my PhD students is working on the notion of niche construction. He takes the idea from biology, looks at the biological debates, and develops a taxonomy of different uses of the term and sees whether they are applicable to business niche construction. He compares preceding theories of the firm and observes that they often downplay relevant processes of interaction between businesses and their environment. So we can get inspiration of all sorts from biology. But generalizing Darwinism is not dependent on raiding everything from the biological store. We can often get insights from other sciences too. We can get insight from anthropology, complex systems theory, and even from some forms of mathematics. This is a way that science progresses: by combining ideas from different domains, synthesizing them, and obtaining new understandings.

Unlike many other institutionalist economists you have been sensitive to methodological questions throughout your work. For example you have written extensively on the issue of methodological individualism (Hodgson 1986; 2007). Is there a danger that a multidisciplinary account such as you just suggested will lead to a whole variety of serious methodological difficulties?

I will respond on methodological individualism and then answer your question on methodological problems. In 2007 I published an article on methodological individualism in the Journal of Economic Methodology. I argue there that everyone in the social sciences, as far as we are aware, ends up explaining social phenomena in terms of both individuals and relations between individuals. Kenneth Arrow says much the same thing in the American Economic Review (1994). For Arrow, even general equilibrium explanations involve structured relations between agents. We know of no exception to this rule. We always have to explain in terms of individuals and relations among individuals. When social 
theorists mention structure they mean relations between individuals. So every successful explanation in the social sciences involves some combination of individuals and structures. There are forms of Marxism where individuals are pushed out of the picture. But structure alone cannot explain things, and anyway without individuals there can be no structure.

Methodological individualists are extremely shady and imprecise about what they mean by the term. There are several definitions of methodological individualism and some protagonists shift from one meaning to another. I ask a methodological individualist: Do you believe that explanations can and should be in terms of individuals alone? Or do you believe explanations can and should be in term of individuals and relations between individuals? If they are foolish enough to take the first option-involving individuals alone-then I say: Please show me one successful example of such an explanation. So far I have not been shown one.

Concerning the second option, my argument is: Why call this methodological individualism? There are two explanatory elements in this story which are both foundational: individuals and relations between individuals. So, if you call it methodological individualism you are stressing half of the story. A structuralist could call this methodological structuralism and be equally in error. It is an equal bias, in the opposite direction. Both would be wrong. They would commit the same error of stressing one explanatory element and not the other.

Should we follow Joseph Agassi (1975) and call it institutionalist individualism? Here I question why one term is a noun and the other an adjective. Why not individualist institutionalism? Again the symmetry of explanatory elements, 'institutional individualism' is biased in its choice of adjective and noun. Overall, methodological individualism suffers from a deep ambiguity. By saying precisely what it means we can get rid of a lot of fog and confusion. We can transcend silly debates which are caught up in ambiguity and may have other agendas behind them.

You ask what problems we face as institutionalists in understanding institutions from a methodological point of view. Following work in that area in the 1980s and 1990s involving Anthony Giddens, Roy Bashkar and others, a key question is the relation between the individual agent and social structure, and in what sense there is mutual determination of one by the other. But social theory has become unpopular because it is perceived to have got down in the wrong kind of issues, methodological 
individualism being an example. I think that this rejection of social theory is over-hasty and mistaken. Many sociologists and social scientists said: 'A plague on both houses! This is getting us nowhere! Let us escape from this mess and just build models, gather data or whatever'. That is a foolhardy reaction, because neither theory nor empirics are possible without implicit or explicit methodological underpinnings. I think a number of critics have observed that when people try to ditch these issues they end up bringing them in through the backdoor. We cannot escape from these fundamental problems of social science.

I argue that evolutionary theory helps us in this area too. Some social theorists offer a model of the social world where agents just appear with beliefs. They may give us a rich story about interaction between agents, mutually constitutive agents and structures, and agents facing constraints bequeathed by history. All this is important, but they give us an inadequate account of the origins and development of the human agent. They commit the same error as Marxism, omitting a causal account of agency itself. There is here an evolutionary story in terms of the development of the individual-how individuals have developed in particular cultural and institutional settings-and there is an evolutionary story about how these dispositions are transmitted, genetically and otherwise, through time. Marxists, critical realists, and many other social scientists ignore that.

We have been talking already about the fragmentation of institutional economics. On the one hand, there is certainly a lot of epistemic plausibility to the idea of exploring a problem from different points of view, and few people would object to pluralism in some form. On the other hand, I have the concern that this pluralism has a potentially problematic downside with respect to achieving cumulative progress in the field, both theoretically and empirically. Do you see any danger of this sort and, if so, how do you think it should be dealt with?

Some people are against pluralism. Some economists define their subject in a way which excludes whole domains of alternative inquiry and alternative methodologies. But let us move on to your main question. When the pluralism debate was reignited in the mid 1990s, I was a participant. There was a conference in Bergamo in Italy. Uskali Mäki, Sheila Dow, Wade Hands and others participated. A book, Pluralism in economics, edited by Andrea Salanati and Ernesto Screpanti 
(1997), came out of it. Several contributions in that book made the point that there is an ambiguity in the concept of pluralism. Does it refer to pluralism in the mind of a single individual, or to pluralism in the academy? People seemingly unaware of these earlier contributions-and of that book in particular-have reiterated the same point over and over again that was raised right at the beginning.

My view is that pluralism in a single head is a recipe for nonsense, because if you hold contradictory ideas then you can logically crank out all sorts of absurd propositions. So I am not some kind of new-age philosopher who believes that you can get on with conflicting ideas. We do have conflicting ideas, but we have to try and reconcile them. Science sometimes adopts different assumptions in different domains. But eventually scientists have to worry about that, as economists worried about the discrepancy between general equilibrium and Keynesian theory. They resolved that in a wrong way, but nevertheless they were right to worry about it. So pluralism in a single head is something to be fought against and overcome. I am against that kind of pluralism. Even if I may be inconsistent sometimes myself, I would like to be corrected and to move towards a consistent position.

But I am in favour of pluralism in the academy. Pluralism there is important for making progress in science. Without a variety of views, everyone is locked into one groupthink way of seeing the world, and things do not change. We know from the history of science that things change when someone brings in new ideas and these clash with the old. Some new approach emerges and in some cases new approaches prove to be robust and useful in scientific terms. Without variety, there would be little chance of generating progress and novelty in science.

On the other hand, if we have an extreme amount of variety in the academy, then we would have chaos and no progress at all. We would be constantly attacking every position from a variety of angles, disallowing any possibility of development clustering around an approach or paradigm or set of principles, and preventing it from taking off scientifically. Neither extreme is conducive to the development of science. Such an argument has been made very powerfully by Philip Kitcher in his 1993 book The advancement of science, where he considers the optimal degree of pluralism in the academy. Part of such a sophisticated pluralism involves rejecting ideas and screening out things which seem untenable. We know that is risky. We know that if you exclude things the chances are that some fruitful lines of inquiry 
will be lost. They will be casualties. But we do need the capacity to build up critical masses of enquirers thinking along similar lines, so that a division of labour within that particular paradigm can be established and research can move forward.

It is a delicate balance and a difficult problem. There is no simple formula. But I am in favour of pluralism in the academy and I think that economics has gone too far in repressing dissent and minimizing variance-so far that by the 1980s you had to conform to a whole set of principles simply to be admitted into the discipline. There has been some significant increase in pluralism since then. It is now legitimate to challenge the core rationality assumption using behavioural economics or experimental research. There is some sign of progress, but I still think that economics is insufficiently diverse. I support those who argue for greater pluralism in economics, but we should also reflect on the limitations of pluralism. There is an urgent need to develop new theoretical approaches. That means the clustering together of people with similar ideas, rather than endlessly piling diversity upon diversity.

\section{You say some things should be excluded. On which grounds would you exclude ideas in institutional economics?}

There are some relatively simple initial tests. We reject ideas that are ungrounded in the existing literature, for example. We occasionally come across people from business and elsewhere who claim to have valuable scientific ideas and insights. My reaction is often: That is very interesting, but you have got to make it much more rigorous, and you have got to show how it relates to previous thinking. This is sometimes not the answer they want to hear because that means they have got to do a lot more work to get it there. Maybe I am turning away people with brilliant ideas simply by that negative response, but I think that is one condition for entering the academy.

Other criteria are more difficult. I have rejected the notion of an immediate explanatory payoff. With such a criterion Darwin would have been stopped when he came back from the Galapagos: This is interesting, but not worth pursuing; we cannot see where you are going. Darwin would not have gotten a research grant-he did not need one fortunately. We would have stopped a lot of research at birth if we asked for immediate results.

But the reaction of the peer group is vital. Kitcher's insight is that science is not to be understood simply as a set of individuals engaging 
with the world and trying to understand it. Science is a communal process, with its own vital institutions. This is an epistemic community, where each individual is dependent on the others and the community itself establishes standards. That does not rule out the possibility of something going wrong. Because of the scientific failure of its own institutional mechanisms, economics to some degree has gotten sick, as Mark Blaug and others have observed.

Let us try to turn institutional economics towards politics. Do you see a potential role for institutional economics in policy application and, if so, what would this role look like?

My work has not been very close to policy application. I am interested in political problems: I have political views, and I am critical of free market economics. But I do not have that much experience in moving from middle range theory towards policy application. Other people are very good at that. Elinor Ostrom is a very fine example, I find her work inspiring and immensely valuable in helping us understand the key role of institutions and it also has immediate policy implications.

However, in a recent paper (Hodgson 2009b) you analyze the role of economics in the crash of 2008. What do you regard as the key factors behind the failure of economics to predict this financial crisis?

Failure of prediction is an interesting issue. We may consider those who claim to have predicted the crash and to give credit where credit is due. But after a point it becomes a very difficult question to answer because all sorts of people have written: This cannot go on! There is too much debt! And so on. But is that a prediction?

It is just as interesting to consider what reception the prophets of doom received in the academic community. Here we have evidence of a failure to acknowledge the possibility and also a prominent mechanism of dismissal, in the form of the observation: You haven't got a model! This was the response to Nouriel Roubini when he spoke at the International Monetary Fund in 2006: 'Where is your model? Is it simply rhetoric? Is it simply descriptive stuff? Unless you have got a model I am not going to take you seriously!' This is a highly biased epistemic screening device that economists have been regrettably trained to take seriously. It meant that economics was not alerted to a potential problem. Also at play was the ideology of free markets, where free markets can do little wrong and there is no extra-market remedy 
for a downturn. At root a combination of free market ideology and inappropriate epistemic screening led to a limited number and weighting of relevant warnings of impending disaster.

To their credit, Paul Krugman and others have come out and criticized the profession for its failure. But I think it is amazing that we have had the greatest economic crash since the Great Depression, but so little in-depth discussion or self-reflection by economists on possible internal flaws in economics itself, which in turn might help to account for its failings and help us to deal with them practically. There is some discussion along those lines, but it is muted, inadequate, and surrounded by indifference. So this has become a crisis for economics as well as a crisis for the economy. We have to act. That means raising serious questions and trying to get good answers to them.

\section{Do you actually see, for instance in Great Britain, that economics as a science is really coming under pressure from the public for its failures?}

Among sophisticated journalists with some economic training, there is a great deal of criticism, both in Britain and in America, of the profession and its failings. There is criticism of the failure of financial economics to envisage possibilities along the lines that have emerged and the failure of macroeconomics to deal with the crisis. Financial economics focused far too much on money-making instruments, which are often lucrative for those who develop them. But financial economists are not trained to look at the broader picture. They acquire a vested interest in promoting their own financial instruments so as to get lucrative consultancy contracts, rather than playing an ethical role and taking up their responsibility as scientists to forewarn about dangers.

So there is a moral crisis amongst economists as well. I am very much in favour of an initiative from America to establish a professional code for economists. Like doctors we have duties. Our duty is not simply to ourselves: to make money and to get nice academic positions and big research grants and nice consultancy contracts and to go to conferences in exotic places. We may do that, but it is not the main objective of the profession. That objective is to serve society. As scientists we serve by helping to understand how society works and the potentialities and dangers inherent in any institutional process or development. That is our moral duty. The ethic of self-interest which economists seem to believe in has corrupted economics to the point that 
we abstain from our scientific duty. Just as doctors have a duty under the Hippocratic Oath to care for people medically, we should have the equivalent of the Hippocratic Oath to care for the health of the economy and to advise accordingly.

Do you think that the profession will actually change in response to the economic crises of the recent past or will economists just return to business as usual?

A big debate that is going on is whether economics will change from within or will change by being challenged by an alternative locus in the academic community under some other label, perhaps 'political economy'. David Colander is an advocate of the first strategy. But I am not convinced that it is possible. Perhaps we should be pluralists here too: some of us should work to change economics from within, and some of us should work to change it from without.

One last question, maybe as a general conclusion. What would you regard as the key achievements of new institutional economics so far, and where do you see its main challenges for the future?

Its key achievement, which is very big, is to put institutions back on the agenda. They were on the agenda in previous schools of economics but they somehow slipped off. When I was studying economics in the 1960s we were often presented with an institution-free world. The firm was a black-box. The state was just a point in space outside the system. So we knew very little about institutions. The new institutional economics has put institutions back on the agenda, not only in terms of minority academic inquiry, but also in all sorts of policy institutes like the World Bank, the International Monetary Fund, and so on. These agencies take institutions very seriously now.

But there are a number of important challenges. The problems I have raised in this interview concerning structure and agency, concerning the role of downward as well as upward causation, and explaining ongoing change are fundamental. I think we also have to make progress in terms of developing more middle-range theory and we have to make further progress in developing applications of such analysis. There are key problems that remain unresolved, such as the causes of firm performance and the determination of their structure and boundaries. The interface between economics and law needs to be rethought and reconstructed. We need a better theory of the individual. We also have to 
reconstruct welfare economics in the light of institutional and evolutionary insights. I could go on, but there is enough here to keep us occupied.

\section{REFERENCES}

Aoki, Masahiko. 1990. Towards an economic model of the Japanese firm. Journal of Economic Literature, 26 (1): 1-27.

Aoki, Masahiko. 2001. Toward a comparative institutional analysis. Cambridge (MA): MIT Press.

Arrow, Kenneth J. 1994. Methodological individualism and social knowledge. American Economic Review, 84 (2): 1-9.

Coase, Ronald H. 1937. The nature of the firm. Economica, 4 (16): 386-405.

Dennett, Daniel C. 1995. Darwin's dangerous idea: evolution and the meanings of life. London and New York: Allen Lane, and Simon and Schuster.

Foster, John. 2005. The self-organizational perspective on economic evolution: a unifying paradigm. In The evolutionary foundations of economics, ed. Kurt Dopfer. Cambridge and New York: Cambridge University Press, 367-390.

Hodgson, Geoffrey M. 1977. Socialism and parliamentary democracy. Nottingham: Spokesman.

Hodgson, Geoffrey M. 1986. Behind methodological individualism. Cambridge Journal of Economics, 10 (3): 211-224.

Hodgson, Geoffrey M. 1988. Economics and institutions: a manifesto for a modern institutional economics. Cambridge: Polity Press.

Hodgson, Geoffrey M. 1993. Economics and evolution: bringing life back into economics. Cambridge: Polity Press.

Hodgson, Geoffrey M. 2001. How economics forgot history: the problem of historical specificity in social science. London: Routledge.

Hodgson, Geoffrey M. 2004. The evolution of institutional economics: agency, structure and Darwinism in American institutionalism. London: Routledge.

Hodgson, Geoffrey M. 2006. What are institutions? Journal of Economic Issues, 40 (1): 125.

Hodgson, Geoffrey M. 2007. Meanings of methodological individualism. Journal of Economic Methodology, 14 (2): 211-226.

Hodgson, Geoffrey M. 2009a. On the institutional foundations of law: the insufficiency of custom and private ordering. Journal of Economic Issues, 43 (1): 143-166.

Hodgson, Geoffrey M. 2009b. The great crash of 2008 and the reform of economics. Cambridge Journal of Economics, 33 (6): 1205-1221.

Hodgson, Geoffrey M., and Thorbjørn Knudsen. 2004. The complex evolution of a simple traffic convention: the functions and implications of habit. Journal of Economic Behavior and Organization, 54 (1): 19-47.

Hodgson, Geoffrey M., and Thorbjørn Knudsen. 2006. Why we need a generalized Darwinism: and why a generalized Darwinism is not enough. Journal of Economic Behavior and Organization, 61 (1): 1-19.

Hodgson, Geoffrey M., and Thorbjørn Knudsen. 2010. Darwin's conjecture: the search for general principles of social and economic evolution. Chicago: University of Chicago Press. 
Hull, David L. 1988. Science as a process: an evolutionary account of the social and conceptual development of science. Chicago: The University of Chicago Press.

Kitcher, Philip. 1993. The advancement of science: science without legend, objectivity without illusions. Oxford: Oxford University Press.

Merton, Robert K. 1968 [1949]. Social theory and social structure. Glencoe (IL): Free Press.

Milgram, Stanley. 1974. Obedience to authority: an experimental view. New York: Harpercollins.

Nelson, Richard R. 2006. Evolutionary social science and universal Darwinism. Journal of Evolutionary Economics, 16 (5): 491-510.

Nelson, Richard R., and Sidney G. Winter. 1982. An evolutionary theory of economic change. Cambridge (MA): Belknap Press of Harvard University Press.

North, Douglass C. 1990. Institutions, institutional change and economic performance. Cambridge: Cambridge University Press.

North, Douglass C. 1994. Economic performance through time. American Economic Review, 84 (3): 359-367.

Salanati, Andrea, and Ernesto Screpanti. 1997. Pluralism in economics: new perspectives in history and methodology. Cheltenham: Edward Elgar.

Shannon, Claude E., and Warren Weaver. 1949. The mathematical theory of communication. Chicago: University of Illinois Press.

Sraffa, Piero. 1960. Production of commodities by means of commodities: prelude to a critique of economic theory. Cambridge: Cambridge University Press.

Williamson, Oliver W. 1975. Markets and hierarchies, analysis and antitrust implications: a study in the economics of internal organization. New York: Free Press.

Witt, Ulrich. 1997. Self-organisation and economics: what is new? Structural Change and Economic Dynamics, 8 (4): 489-507.

Geoffrey Hodgson's Website: <http://www.geoffrey-hodgson.info> 